Article

\title{
New Pharmaceutical Salts of Trazodone
}

\author{
Jolanta Jaśkowska ${ }^{1, *(\mathbb{D}}$, Przemysław Zaręba ${ }^{1}$, Anna Drabczyk ${ }^{1}$, Agnieszka Kozak ${ }^{2}$, Izabela D. Madura ${ }^{3}{ }^{(1)}$, \\ Zbigniew Majka ${ }^{4}$ and Edyta Pindelska ${ }^{2, *(1)}$
}

1 Institute of Organic Chemistry and Technology, Faculty of Chemical and Engineering and Technology, Cracow University of Technology, 24 Warszawska Street, 31-155 Cracow, Poland; przemyslaw.zareba@pk.edu.pl (P.Z.); anna.drabczyk@pk.edu.pl (A.D.)

2 Department of Analytical Chemistry and Biomaterials, Faculty of Pharmacy, Medical University of Warsaw, Banacha 1, 02-093 Warsaw, Poland; asokal@wum.edu.pl

3 Faculty of Chemistry, Warsaw University of Technology, Noakowskiego 3, 00-664 Warsaw, Poland; izabela@ch.pw.edu.pl

4 Zbigniew Majka Consulting, ul Górczewska 200c /58, 01-460 Warszawa, Poland; zbig_majka@wp.pl

* Correspondence: jolanta.jaskowska@pk.edu.pl (J.J.); edyta.pindelska@wum.edu.pl (E.P.); Tel.: +48-12-628-27-40 (J.J.); Tel.: +48-22-572-07-57 (E.P.)

check for

updates

Citation: Jaśkowska, J.; Zaręba, P.; Drabczyk, A.; Kozak, A.; Madura, I.D.; Majka, Z.; Pindelska, E. New Pharmaceutical Salts of Trazodone. Molecules 2021, 26, 769. https:// doi.org/10.3390/molecules26030769

Academic Editor: Pradip K. Bhowmik Received: 23 December 2020

Accepted: 26 January 2021

Published: 2 February 2021

Publisher's Note: MDPI stays neutral with regard to jurisdictional claims in published maps and institutional affiliations.

Copyright: (c) 2021 by the authors. Licensee MDPI, Basel, Switzerland. This article is an open access article distributed under the terms and conditions of the Creative Commons Attribution (CC BY) license (https:// creativecommons.org/licenses/by/ $4.0 /)$.

\begin{abstract}
New pharmaceutically acceptable salts of trazodone (trazodone hydrogen bromide and trazodone 1-hydroxy-2-naphthonic acid) for the treatment of central nervous system disorders are synthesized and described. Although trazodone salts are poorly crystalline, single-crystal X-ray diffraction data for trazodone 1-hydroxy-2-naphthonic acid were collected and analyzed as well as compared to the previously described crystal structure of commercially available trazodone hydrochloride. The powder samples of all new salts were characterized by Fourier transform infrared spectroscopy, $\mathrm{X}$-ray diffraction and ${ }^{13} \mathrm{C}$ solid-state nuclear magnetic resonance spectroscopy. Spectroscopic studies were supported by gauge including projector augmented wave (GIPAW) calculations of carbon chemical shielding constants. The main goal of our research was to find salts with better physicochemical properties and to make an attempt to associate them with both the anion structure and the most prominent interactions exhibited by the protonated trazodone cation. The dissolution profiles of trazodone from tablets prepared from various salts with lactose monohydrate were investigated. The studies revealed that salts with simple anions show a fast release of the drug while the presence of more complex anion, more strongly interacting with the cation, effects a slow-release profile of the active substance and can be used for the preparation of the tables with a delay or prolonged mode of action.
\end{abstract}

Keywords: trazodone; drug design; dissolution; crystal structure; solid-state NMR (SSNMR) spectroscopy; GIPAW calculation

\section{Introduction}

2-\{3-[4-(3-Chlorophenyl)-piperazin-1-yl]-propyl\}-[1,2,4]-triazolo-[4,3-a]-pyridin-3-(2H)one, known as "trazodone", is used to treat mood disorders, such as depression [1]. Trazodone belongs to the group of drugs that block serotonin receptors and inhibit the reuptake of serotonin (SARI) [2]. It was introduced into medicine in the early 1970s, and in the 1980s it was the most frequently prescribed antidepressant in the United States [3,4]. The subsequent introduction and promotion of drugs inhibiting serotonin reuptake (SSRI) resulted in a decrease in interest in antidepressants with a different mechanism of action, but the analysis of the pharmacological profile of trazodone allowed for the extension of therapeutic indications and recognition of its many possibilities. Today, this drug has once again found a prominent place in the pharmacological treatment of depression. One of the new, very promising additional indications is the possibility of using trazodone in patients with neuropathic pain in the course of neoplastic disease [5]. Trazodone is an antagonist of $5-\mathrm{HT}_{2 \mathrm{~A}}$ and $5-\mathrm{HT}_{2 \mathrm{C}}$ receptors and an inhibitor of the serotonin transporter (SERT). Besides, 
it blocks adrenergic receptors $-\alpha_{1}$ and $\alpha_{2}$ and histamine $\mathrm{H}_{1}$. Unlike other antidepressants, trazodone has a weak effect on transporters of other amines: dopamine (DAT) or noradrenaline (NET) [6]. In the case of trazodone, the therapeutic dose is 75-100 mg daily in a single dose, the dose can be increased to $300 \mathrm{mg}$ daily in divided doses. In justified cases, the dose may be increased to $600 \mathrm{mg}$ per day.

There are several methods of obtaining trazodone known, yet recently a new method via the reaction of 2-(3-halopropyl)-1,2,4-triazolo-[4,3-a]-pyridin-3-(2H)-one and 1-(3-chlorophenyl) piperazine hydrochloride under microwave radiation in the presence of potassium carbonate has been developed [7]. However, to search for more effective methods of pharmacotherapy, not only new medicinal substances are sought, but also new forms of administration of already known drugs. Modifying the form of a drug may change the pharmacokinetics of release, and thus a sustained-release (SR) or controlled-release (CR) dosage can be obtained. It is important to underline that the drug substances with the altered release time must be well known and must have a defined relationship between a dose and its therapeutic action.

More than $80 \%$ of all dosage forms of drugs are administered orally. However, it carries some barriers related to absorption, e.g., extreme fluctuating $\mathrm{pH}$ of the stomach, the activity of enzymatic systems, the permeability of mucus covering the gastrointestinal tract [8,9]. Additionally, the physiological conditions in the gastrointestinal tract, such as variable passage speed or the amount of fluid, can significantly affect bioavailability [10]. Hence, modified-release drug forms are being developed to limit the influence of physiological factors and to have greater control over bioavailability, and thus also limit fluctuations in blood concentration of the administered substance [8,9]. For the orally administered drugs, retarded forms are often desirable. They can provide increased protection of the gastrointestinal tract against the harmful effects of the active substance or improve bioavailability by releasing the drug at a specific site in the gastrointestinal tract [10-13]. Moreover, with appropriately modified drugs it is also possible to obtain very good therapeutic effects, often with reduced therapeutic doses of active substances and, at the same time, the limitation of side effects [11].

In pharmaceutical practice, only trazodone hydrochloride (T:HCl) is commercially produced (e.g., Trazodone Neuraxpharm (Trazodone Glenmark)-Neuraxpharm, Trittico ${ }^{\circledR} \mathrm{CR}$ or Trittico ${ }^{\circledR}$ XR-Angelini). Although synthesis of several trazodone salts has been described in the literature (e.g., sulfate, succinate, maleate, $p$-toluene sulfonate [14], benzoate [15], acetate, propionate, methanesulfonate, ethanesulfonate, benzeneacetate, phosphate, decanoate, oleate, citrate, tartrate, embonate [16], benzilate [17], 2,4-dinitrophenolate [18], nitrate, thiocyanate, tetrafluoroborate [19], iodide, oxalate [20]) the systematic studies connecting the pharmaceutical properties such as dissolution profiles from tablets with the anion structure have never been performed. Herein, we present the dissolution profiles of four trazadone salts from ready-to-sell tablets with lactose (LA). The selected salts are the two newly obtained trazadone hydrobromide (T:HBr) and 1-hydroxy-2-naphthonic acid (T:OHN) as well as trazadone embonic acid (T:EM) and hydrochloride (T:HCl) (Figure 1). These studies are followed by comparative structural analysis of T:OHN and T:HCl crystals to reveal if the anion-cation interactions influence the time required for drug dissolution. 


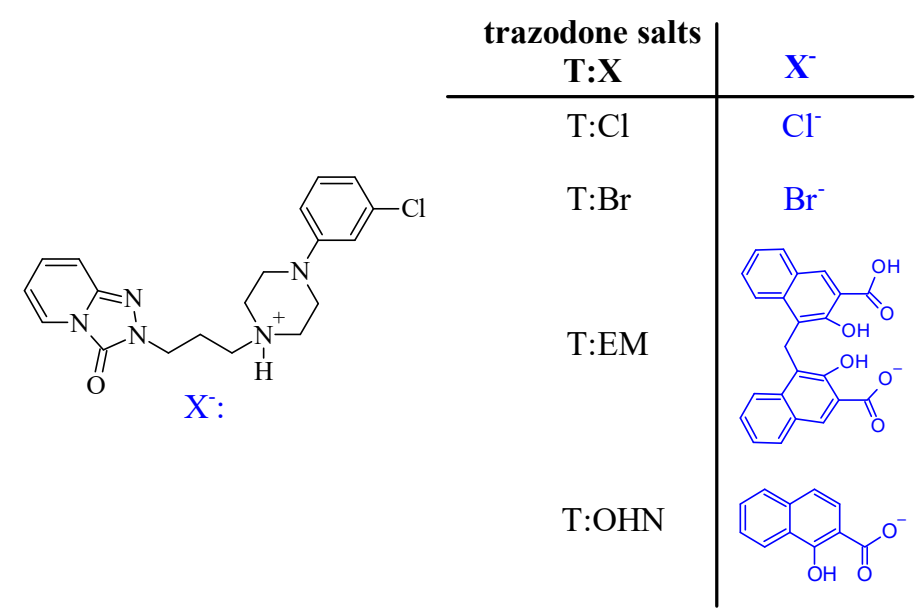

Figure 1. The studied trazodone salts: hydrochloride (T:HCl), hydrobromide (T:HBr), 1-hydroxy-2naphthonic acid (T:OHN) and embonate (T:EM).

\section{Results and Discussion}

Trazodone was obtained in a solvent-free method of synthesis in the field of microwave radiation under PTC (Phase Transfer Catalysis) conditions [7,21]. The salts were obtained in a reaction with a hydrobromic acid (2 methods) and 1-hydroxy-2-naphthoic acid (3 methods). The T:HBr salt synthesis was carried out in acetone or methanol, then the product was crystallized from ethanol to yield $46-86 \%$ yield. The T:OHN salt was obtained by the reaction in acetone, methanol, or ethyl acetate, the product was obtained in a $31-57 \%$ yield and did not require additional crystallization [22].

Among all pharmaceutical dosage forms, tablets represent the most popular API delivery system, exhibiting numerous advantages compared to other drug forms. However, only some drugs can be tableted directly without the addition of any excipients, mostly due to diversified active pharmaceutical ingredients (API) stability, which can change, for example upon pressure. On the other hand, the addition of even a small amount of excipients may also change the stability or solubility of the active substances in tablets. In the case of the tested trazodone compounds, we were unable to prepare pure API tablets. During the compression process, the API melted or transformed into another, unstable polymorphic form with a color change. To compare the properties of different trazodone salts from tablets, we prepared tablets with the addition of lactose monohydrate. It is a frequently used excipient, often significantly improving the quality of tablets obtained, as it was also observed with the tablets we prepared (the amount of trazodone in the tablet was set to $75 \mathrm{mg}$, according to the minimum dose of the drug in the already marketed products, e.g., Trittico $\mathrm{CR}^{\circledR}$ ).

The first factor we decided to measure was the time for a tablet disintegration (Table 1). The disintegration is an important process, which influences a drug bioavailability and ensures its expected concentration in the blood in a given time. In the case of tested trazodone compounds the fastest disintegration was observed for the tablets with $\mathrm{T}: \mathrm{HBr}$. This time is 2.5 shorter than the disintegration time of the reference $\mathrm{T}: \mathrm{HCl}$ tablets. To obtain the complete tablet disintegration for T:OHN and T:EM $24 \mathrm{~h}$ were need, and in the case of T:EM the release of only $90 \%$ of the API was achieved. 
Table 1. Tablet disintegration time.

\begin{tabular}{cc}
\hline Tablet Composition & Tablet Disintegration Time \\
\hline T:HCl + LA & $13.5 \mathrm{~min}$ \\
T:HBr + LA & $5.5 \mathrm{~min}$ \\
T:OHN + LA & more than 24 h: after this time, approximately $100 \%$ of the API \\
& was released from tablets with LA \\
T:EM + LA & more than 24 h: after this time, approximately $90 \%$ of the API was \\
& released from the tablet with LA \\
\hline
\end{tabular}

To fully compare the properties of the newly obtained stats we evaluated the dissolution profiles of trazodone from tablets containing studied trazodone compounds with lactose monohydrate (LA) addition. Profiles of the trazodone release from T:HCl + LA, T:HBr + LA, T:OHN + LA, T:EM + LA tablets are shown in Figure 2.

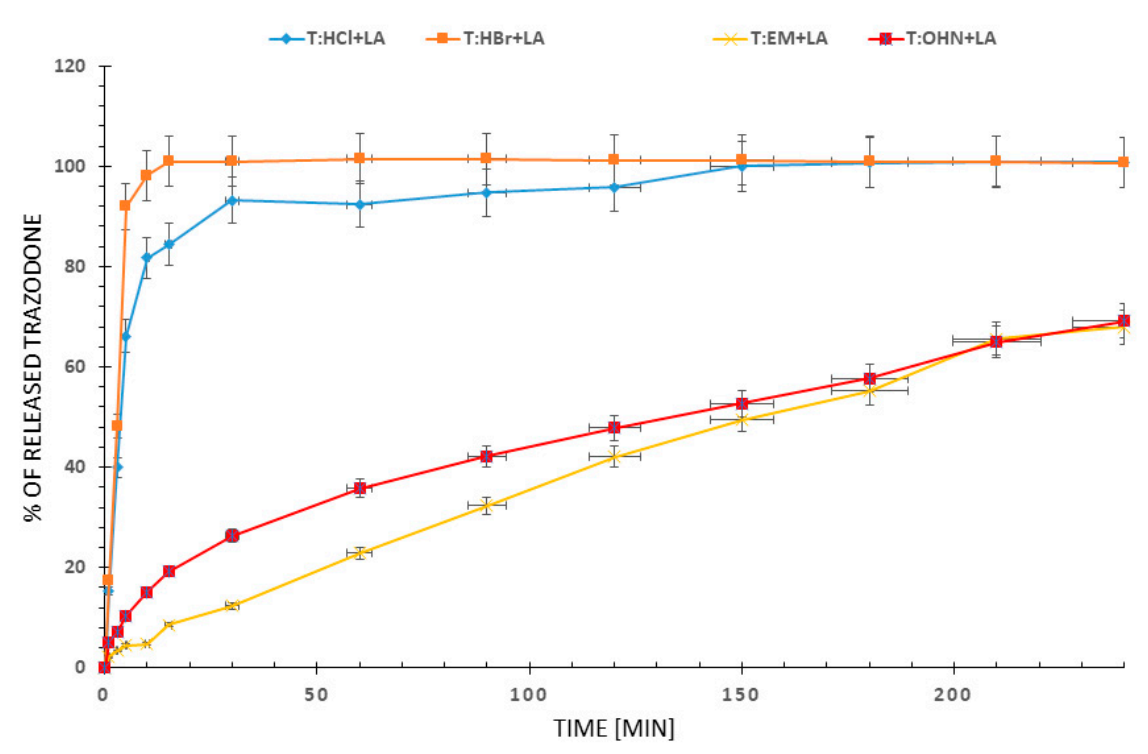

Figure 2. Dissolution profiles in $0.01 \mathrm{M} \mathrm{HCl}$ from tablets of studied trazodone salts with lactose monohydrate. The $5 \%$ error bars are shown.

The maximum trazodone release in $0.01 \mathrm{M} \mathrm{HCl}$ from reference $\mathrm{T}: \mathrm{HCl}+\mathrm{LA}$ tablets is achieved in the first two hours, whereas for all other compounds different time was needed-about $10 \mathrm{~min}$ for T:HBr + LA and more than $4 \mathrm{~h}$ for T:EM + LA and T:OHN + LA. The best dissolution profile from the pharmaceutical point of view has the $\mathrm{T}: \mathrm{HBr}+\mathrm{LA}$ tablet. In this case, $100 \%$ of the API is released during the first $10 \mathrm{~min}$, so a fast mode of action may be assumed. In contrast, in the case of T:EM and T:OHN, the slow dissolution of the drug can be an advantage in the manufacture of prolonged-release tablets. From a therapeutic perspective, this retarded release might be very promising in curing the depression, presumably with a lower or less frequent dosage than usually taken by a patient [11].

One may notice that the dissolution profiles of simple anions (chloride and bromide) differ substantially from the profiles obtained for bigger anions (1-hydroxy-2-naphthoate and embonate). Hence, it might be interesting to compare the trazodone cation structure and its interactions in crystals of these salts and relate it to the dissolution properties. Below, we present the scrutinized analysis of crystal structures for the candidates for tablets of fast (chloride) and slow (1-hydroxy-2-naphthoate) modes of action. It should be emphasized that trazodone salts are weakly crystalline, as evidenced by a small number of structures deposited in the Cambridge Structural Database (CSD) [23]. So far, only seven salts have been structurally characterized [18-20]. The crystal structure of T:HCl is deposited in the CSD under the refcode CPTAZP [24]. Although there was no need to obtain a single crystal 
for X-ray experiments the data have to be improved by adding the positions of hydrogen atoms relative to the position of heavy atoms [25].

Both salts, $\mathrm{T}: \mathrm{HCl}$ and newly obtained T:OHN, crystalize in the monoclinic system in space symmetry groups $P 2_{1} / c$ and $P 2_{1} / n$, respectively. In the case of T:OHN, except for the anion and cation pair one water molecule is present in the asymmetric part of the unit cell (Figure 3a,b).

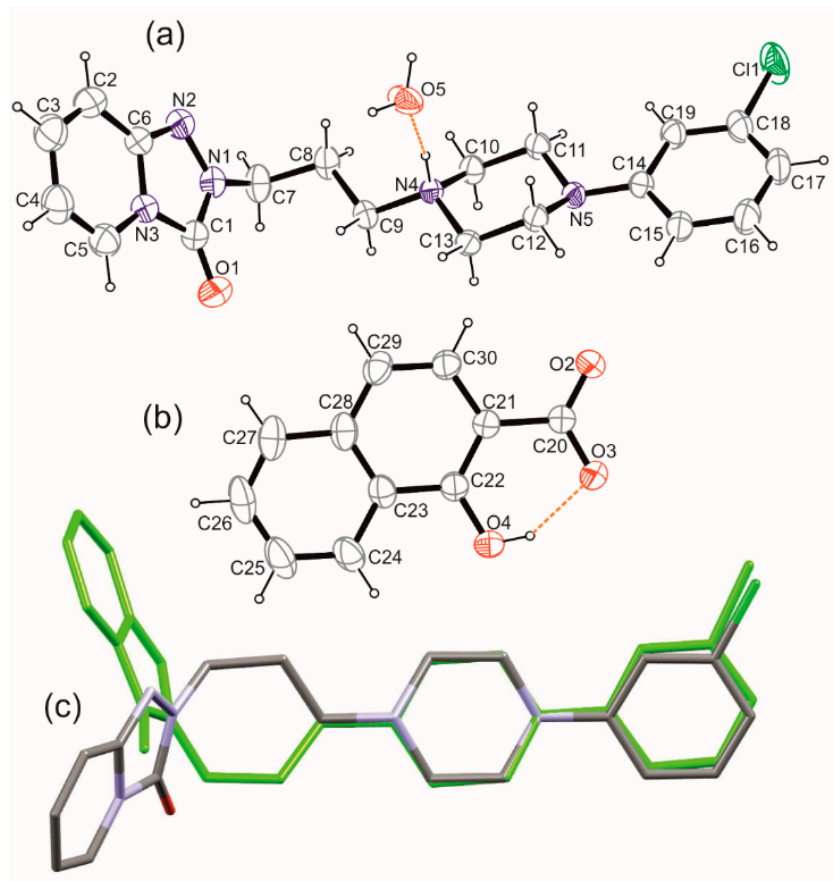

Figure 3. Ortep [26] drawing with the atom numbering scheme of (a) the cation with interacting water molecule and (b) anion in T:OHN salt. Thermal displacement ellipsoids are drawn with $30 \%$ probability. Hydrogen bonds are depicted as dashed lines. (c) Overlay of cations in T:HCl (green) and T:OHN crystals.

The comparison of the protonated trazodone molecules in both salts revealed that they are different rotamers considering on the $\mathrm{C} 9-\mathrm{N} 4$ bond (Figure 3c). This is reflected in the C8-C9-N4-C10 torsion angle values equal to 176.11 and $-61.66^{\circ}$ for $\mathrm{T}: \mathrm{HCl}$ and $\mathrm{T}: \mathrm{OHN}$, respectively. Interestingly, on the ${ }^{13} \mathrm{C}$ solid-state NMR spectra (Supplementary Materials Table S1) the difference in chemical shifts for this atom is $2.79 \mathrm{ppm}$ and it is not the biggest one observed. The highest chemical shift differences are present for $\mathrm{C} 15(-6.81 \mathrm{ppm})$ and $\mathrm{C} 19(-4.51 \mathrm{ppm})$ atoms constituting the chlorobenzene ring, C10 (3.95 ppm) and C11 (4.10 ppm) from the piperazine ring, and C2 (3.44 ppm) of the fused pyridine ring (Table S1 and Figure 4). It should be underlined that the calculations of the NMR parameters (the GIPAW DFT method [27-29]) can be particularly helpful in assignments of the signals, as well as may provide a good way to study the dependence of NMR parameters upon structure. The calculated NMR chemical shifts of ${ }^{13} \mathrm{C}$ atoms of $\mathrm{T}: \mathrm{HCl}$ and $\mathrm{T}: \mathrm{OHN}$ were compared with the experimental data to support the NMR spectral assignments (the CASTEP program [30] has been used to calculate carbon atoms chemical shifts and the results are presented in Table S1). It should be emphasized that the theoretical carbon atom chemical shifts are in excellent agreement with the experimental chemical shifts (Supplementary Materials Figures S1 and S2), which proves the correctness of the assignments made. 


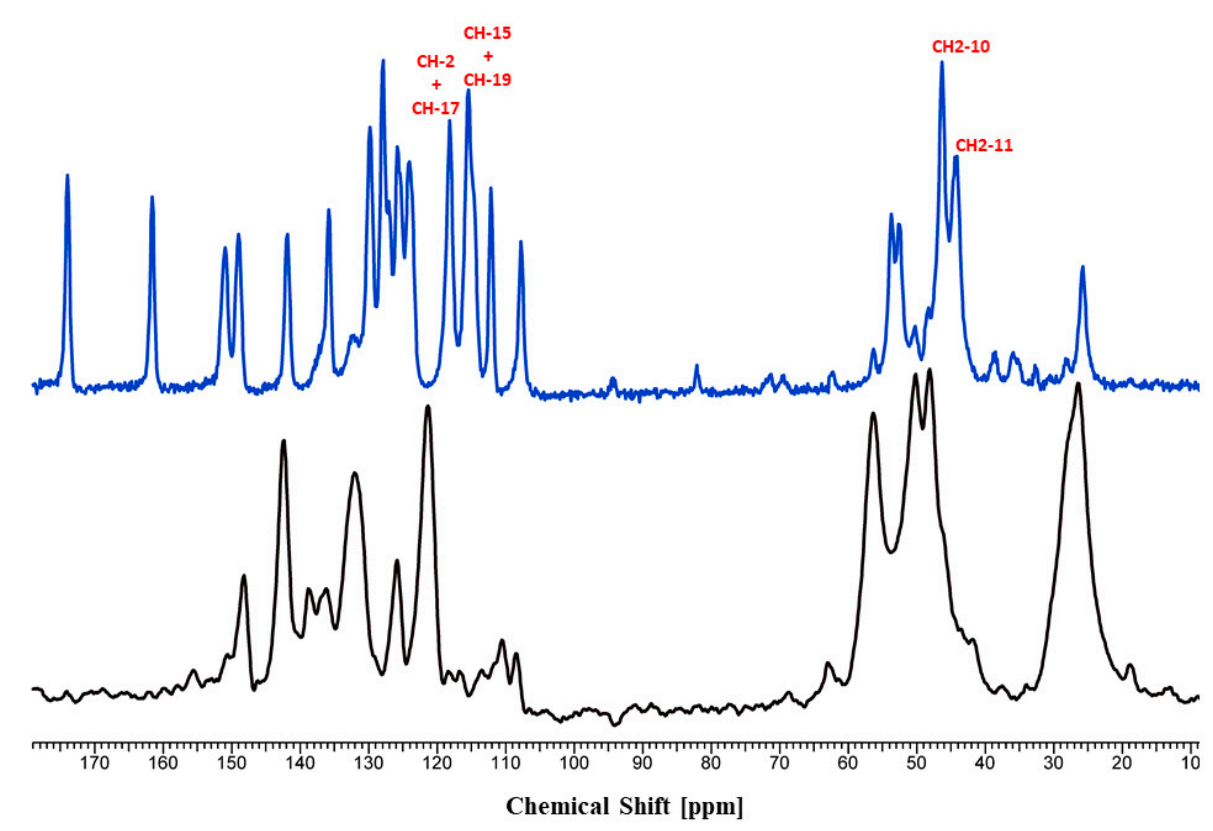

Figure $4 .{ }^{13} \mathrm{C}-\mathrm{CP} / \mathrm{MAS}-\mathrm{NMR}$ spectra of $\mathrm{T}: \mathrm{HCl}$ (black) and the newly obtained salt T:OHN (blue) recorded with a contact time of $4 \mathrm{~ms}$. Spinning sidebands are marked with asterisks.

Previous studies showed that even such small differences in chemical shifts of chemically identical moieties may be attributed to the presence of weak intermolecular interactions, i.e., various hydrogen bonds or aromatic interactions [31-33] In the analyzed structures, the "classical" ( $\mathrm{O}-\mathrm{H}$ and $\mathrm{N}-\mathrm{H}$ donors) and weaker ( $\mathrm{C}-\mathrm{H}$ donors) hydrogen bonds are found in both crystals (Tables S2 and S3). The protonated trazodone molecule in $\mathrm{T}: \mathrm{OHN}$ is interacting with the water molecule and forming the $\mathrm{N}-\mathrm{H} \cdots \mathrm{O}$ hydrogen bond (Figure 3a). Further, the water molecule acts as a double hydrogen bond donor to both oxygen atoms of the carboxylate group of the anion. In effect, an infinite supramolecular chain structure along [101] direction is observed (Figure S4). Taking into account only $\mathrm{O}-\mathrm{H} \cdots \mathrm{O}$ hydrogen bonds, this entity can be described with the second level graph set as $C^{2}{ }_{2}(6)$ [34] and the $p 1 c 1$ rod symmetry group [35]. Therefore, the trazodone cations "decorate" these chains, bonding through $\mathrm{N}-\mathrm{H} \cdots \mathrm{O}$ hydrogen bonds to water molecules. Whereas, in $\mathrm{T}: \mathrm{HCl}$, protonated piperazine interacts with chloride anion forming a definite motif. There are no further strong hydrogen bond donors, though building up 3D crystal structure occurs via weak interactions only (Figure S5).

To elucidate the weak intermolecular interactions, the most convenient method is to compare the molecular Hirshfeld surfaces [36] (Figure 5). They can be represented by surfaces normalized with VdW radii as well as so-called resolved fingerprint plots to show the types of interacting atoms [37]. On both surfaces calculated for cations and depicted with the same scaling, big red spots correspond to $\mathrm{N}-\mathrm{H} \cdots \mathrm{O}$ (water) or $\mathrm{N}-\mathrm{H} \cdots \mathrm{Cl}$ interactions. In the case of T:OHN pale red spots on the surface reflect weak $\mathrm{C}-\mathrm{H} \cdots \mathrm{O}$ interactions, most of them being charge assisted [38], similarly to $\mathrm{C}-\mathrm{H} \cdots \mathrm{Cl}$ interactions in $\mathrm{T}: \mathrm{HCl}$, also visible on the surface together with reasonably short $\mathrm{C}-\mathrm{H} \cdots \mathrm{O}$ contacts. The resolved fingerprint plots showed also a presence of weak $\mathrm{C}-\mathrm{H} \cdots \mathrm{p}$ interactions as well as stacking interactions in T:OHN. This is not surprising, since the anion is composed of two fused six-membered rings that align almost parallelly with the trazodone fused ring system and nearly perpendicularly to the chlorophenyl ring (see Figure S3 in the Supplementary Materials). These interactions are rank as strong ones according to calculations with the Aromatic Interactions module in the Mercury program [25] and thus might be responsible for the observed carbon atoms shielding in the area of the fused ring system and deshielding in the area of chlorophenyl ring in $\mathrm{T}: \mathrm{OHN}$. We may also conjecture that $\mathrm{C}-\mathrm{H} \cdots \mathrm{Cl}$ and $\mathrm{C}-$ $\mathrm{H} \cdots \mathrm{O}$ interactions with donors from piperazine ring are somewhat stronger in $\mathrm{T}: \mathrm{HCl}$ than 
$\mathrm{C}-\mathrm{H} \cdots \mathrm{O}$ and $\mathrm{C}-\mathrm{H} \cdots \pi$ contacts in T:OHN (Tables S2 and S3). What is more, in T:HCl the strongest $\mathrm{C}-\mathrm{H} \cdots \mathrm{O}$ hydrogen bonds join cations into a $1 \mathrm{D}$ chain along $21_{1}$ screw axis and the anions resides in the middle of the cross-section of these chains. Hence, $\mathrm{N}-\mathrm{H} \cdots \mathrm{Cl}$ and $\mathrm{C}-\mathrm{H} \cdots \mathrm{Cl}$ interactions join these chains into a 3D structure. In $\mathrm{T}: \mathrm{OHN}$ chains formed by strong $\mathrm{O}-\mathrm{H}$... $\mathrm{O}$ H-bonds between anion and water molecules are further organized into layers mostly by $\mathrm{C}-\mathrm{H} \cdots \pi$ and $\pi \cdots \pi$ interactions between anion and chlorophenyl ring of trazodone (Figure S4).
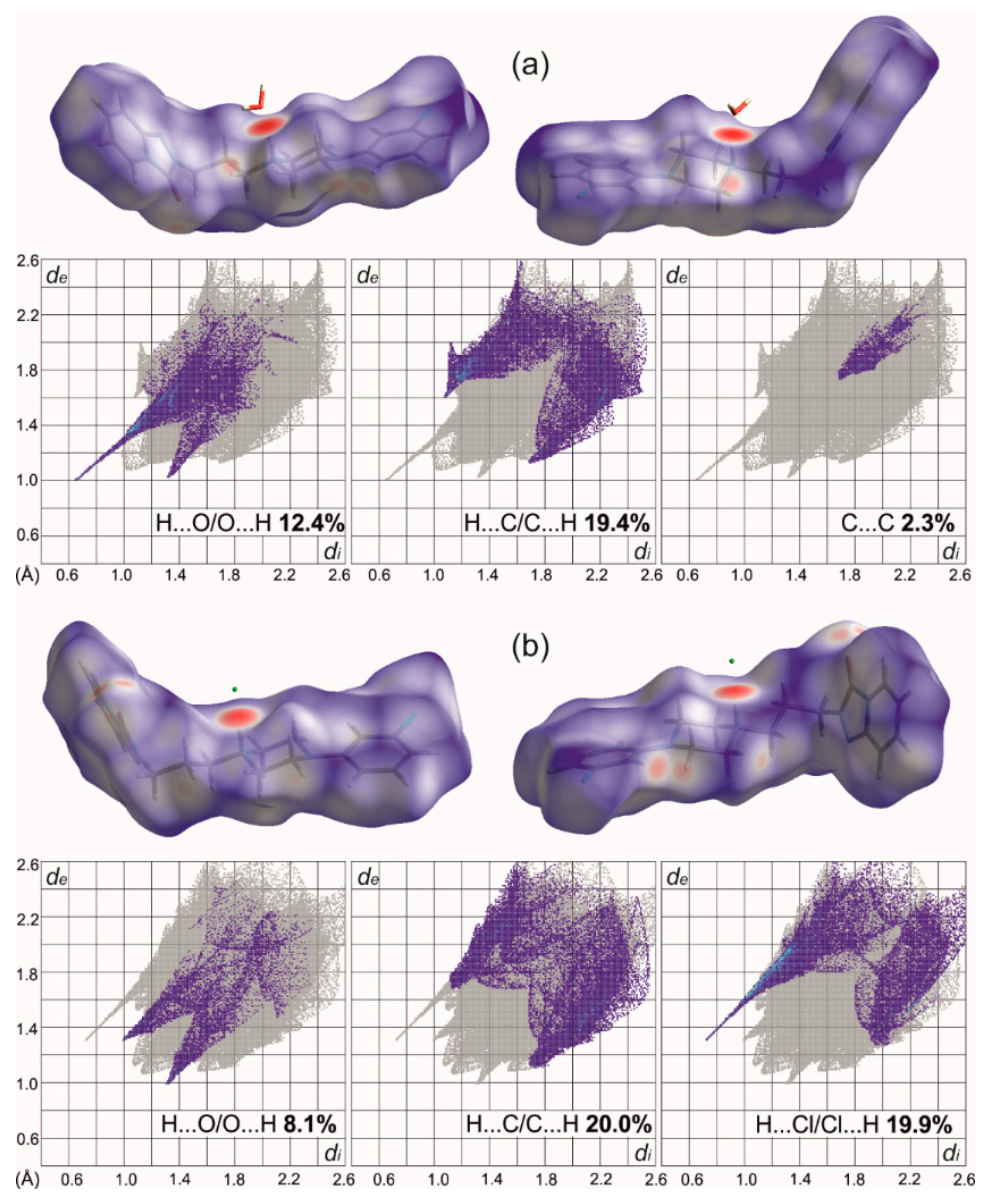

Figure 5. Hirshfeld surfaces (front and rear views) and decomposed fingerprint plots showing the most important interactions in T:OHN (a) and T:HCl (b).

\section{Materials and Methods}

\subsection{Materials/Synthesis}

3.1.1. Synthesis of $\mathrm{T}: \mathrm{HBr}$

\section{Method I}

In a beaker, $0.372 \mathrm{~g}$ of trazodone free base was dissolved in $40 \mathrm{~cm}^{3}$ of acetone by heating the solution to boiling. Concentrated aqueous $\mathrm{HBr}$ solution was then added portion wise until acidic. The solution was then cooled to $4{ }^{\circ} \mathrm{C}$ and kept under these conditions for $24 \mathrm{~h}$. After this time, the resulting amorphous precipitate was filtered off. The crude product was crystallized from ethanol. $\mathrm{Y}=46 \%$.

\section{Method II}

In a beaker, $0.372 \mathrm{~g}$ of trazodone free base was dissolved in $20 \mathrm{~cm}^{3}$ of methanol by heating the solution to boiling. Concentrated aqueous HBr solution was then added portionwise until acidic. The solution was allowed to evaporate the solvent. The crude product was crystallized from ethanol. $\mathrm{Y}=86 \%$. 
T:HBr. UPLC-MS, $\mathrm{t}_{\mathrm{M}}=3.91 \mathrm{~min}$. Elemental analysis, $\left(\mathrm{C}_{19} \mathrm{H}_{23} \mathrm{BrClN}_{5} \mathrm{O}\right) \% \mathrm{C}=29.31$, $\% \mathrm{H}=3.86, \% \mathrm{~N}=8.31 .{ }^{1} \mathrm{H}-\mathrm{NMR}\left(300 \mathrm{MHz}, \mathrm{CDCl}_{3}\right), \delta(\mathrm{ppm}): 7.75(\mathrm{~d}, J=7.1 \mathrm{~Hz}, 1 \mathrm{H}, \mathrm{ArH})$, $7.21(\mathrm{~d}, J=8.1 \mathrm{~Hz}, 1 \mathrm{H}, \mathrm{ArH}), 7.18-7.06(\mathrm{~m}, 2 \mathrm{H}, \mathrm{ArH}), 6.97(\mathrm{~d}, J=7.3 \mathrm{~Hz}, 2 \mathrm{H}, \mathrm{ArH}), 6.84$ $(\mathrm{d}, J=8.9 \mathrm{~Hz}, 1 \mathrm{H}, \mathrm{ArH}), 6.58-6.50(\mathrm{~m}, 1 \mathrm{H}, \mathrm{ArH}), 4.17(\mathrm{t}, J=6.0 \mathrm{~Hz}, 2 \mathrm{H}, \mathrm{CONCH}), 3.88(\mathrm{t}$, $\left.J=12.0 \mathrm{~Hz}, 2 \mathrm{H}, \mathrm{CH}_{\text {Pip }}\right), 3.66$ (s, 4H, $\left.\mathrm{CH}_{\text {Pip }}\right), 3.21$ (dd, $\left.J=16.6,5.2 \mathrm{~Hz}, 2 \mathrm{H}, \mathrm{CH}_{\text {Pip }}\right), 3.08$ (d, $\left.J=12.9 \mathrm{~Hz}, 2 \mathrm{H}, \mathrm{NCH}_{\text {Alif }}\right), 2.59\left(\mathrm{~d}, J=16.8 \mathrm{~Hz}, 2 \mathrm{H}, \mathrm{CH}_{\text {Alif }}\right)$. FT-IR $\left(\mathrm{cm}^{-1}\right), 2983(\mathrm{C}-\mathrm{H}), 2937$; $2860(\mathrm{C}-\mathrm{H}), 1694(\mathrm{C}=\mathrm{O}), 1640(\mathrm{C}=\mathrm{N}), 1594 ; 1491(\mathrm{C}=\mathrm{C}), 1356(\mathrm{C}-\mathrm{N}), 742(\mathrm{C}-\mathrm{Cl})$.

\subsubsection{Synthesis of $\mathrm{T}: \mathrm{OHN}$}

\section{Method I}

A solution of $0.190 \mathrm{~g}$ of 1-hydroxy-2-naphthoic acid in $15 \mathrm{~cm}^{3}$ of methanol was prepared. In a beaker, $0.372 \mathrm{~g}$ of trazodone free base was dissolved in $20 \mathrm{~cm}^{3}$ of methanol by heating the solution to reflux. The 1-hydroxy-2-naphthoic acid solution was then added portionwise while stirring. The solution was cooled to $4{ }^{\circ} \mathrm{C}$ and allowed to crystallize. The resulting crystals were filtered off. $\mathrm{Y}=57 \%$.

\section{Method II}

A solution of $0.190 \mathrm{~g}$ of 1-hydroxy-2-naphthoic acid in $20 \mathrm{~cm}^{3}$ of acetone was prepared. In a beaker, $0.372 \mathrm{~g}$ of trazodone free base was dissolved in $20 \mathrm{~cm}^{3}$ of acetone by heating the solution to boiling. The 1-hydroxy-2-naphthoic acid solution was then added portionwise to the trazodone solution with continued stirring. The solution was cooled to $4{ }^{\circ} \mathrm{C}$ and allowed to crystallize. The resulting crystals were filtered off. $\mathrm{Y}=39 \%$.

\section{Method III}

A solution of $0.190 \mathrm{~g}$ of 1-hydroxy-2-naphthoic acid in $30 \mathrm{~cm}^{3}$ of ethyl acetate is prepared. In a beaker, $0.372 \mathrm{~g}$ of trazodone free base was dissolved in $30 \mathrm{~cm}^{3}$ of ethyl acetate by heating the solution to boiling. The 1-hydroxy-2-naphthoic acid solution was then added portion-wise to the trazodone solution with continued stirring. The solution was cooled to $4{ }^{\circ} \mathrm{C}$ and allowed to crystallize. The resulting crystals were filtered off. $\mathrm{Y}=31 \%$.

T:OHN. UPLC-MS, $\mathrm{t}_{\mathrm{M}}=3.89 \mathrm{~min}$. Elemental analysis, $\left(\mathrm{C}_{30} \mathrm{H}_{30} \mathrm{ClN}_{5} \mathrm{O}_{4}\right) \% \mathrm{C}=62.14$, $\% \mathrm{H}=5.53, \% \mathrm{~N}=12.05 .{ }^{1} \mathrm{H}-\mathrm{NMR}\left(300 \mathrm{MHz}, \mathrm{CDCl}_{3}\right), \delta(\mathrm{ppm}): 8.37(\mathrm{~d}, J=8.3 \mathrm{~Hz}, 1 \mathrm{H}$, $\mathrm{ArH}), 7.83$ (d, J = 8.7 Hz, 1H, ArH), 7.80-7.67 (m, 2H, ArH), 7.59-7.43 (m, 2H, ArH), 7.18 $(\mathrm{dd}, J=18.4,10.2 \mathrm{~Hz}, 2 \mathrm{H}, \mathrm{ArH}), 7.04-6.93(\mathrm{~m}, 2 \mathrm{H}, \mathrm{ArH}), 6.85(\mathrm{t}, J=4.0 \mathrm{~Hz}, 2 \mathrm{H}, \mathrm{ArH})$, 6.80-6.73 (m, 1H, ArH), 6.45 (ddd, $J=7.3,4.9,2.5 \mathrm{~Hz}, 1 \mathrm{H}, \mathrm{ArH}), 4.12(\mathrm{t}, J=6.3 \mathrm{~Hz}, 2 \mathrm{H}$, CONCH), 3.48-3.30 (m, 4H, CH $\mathrm{CPip}_{\text {) }}, 3.13-3.01$ (m, 4H, $\left.\mathrm{CH}_{\text {Pip }}\right), 3.02-2.89$ (m, 2H, NCH Alif $_{\text {), }}$ 2.40-2.29 (m, 2H, CH $\mathrm{Clif}_{\text {if }}$, FT-IR ( $\left.\mathrm{cm}^{-1}\right), 3456(\mathrm{O}-\mathrm{H}), 3042(\mathrm{C}-\mathrm{H} \mathrm{Ar}), 2942 ; 2843(\mathrm{C}-\mathrm{H}), 1716$ $(\mathrm{C}=\mathrm{O}), 1638(\mathrm{C}=\mathrm{N}), 1592 ; 1488(\mathrm{C}=\mathrm{C}), 1375 ; 1262(\mathrm{C}-\mathrm{O}), 1346(\mathrm{C}-\mathrm{N}), 749(\mathrm{C}-\mathrm{Cl})$.

\subsubsection{Synthesis of T:EM}

\section{Method I}

A solution of $0.388 \mathrm{~g}$ of embonic acid in $20 \mathrm{~cm}^{3}$ of $0.1 \mathrm{M} \mathrm{NaOH}$ was prepared. In a beaker, $0.372 \mathrm{~g}$ of trazodone free base was dissolved in $20 \mathrm{~cm}^{3}$ of $0.1 \mathrm{M} \mathrm{HCl}$. The embonic acid solution was added portionwise to the trazodone solution while stirring. The resulting mixture was adjusted to $\mathrm{pH}=7.0$. After cooling to $4^{\circ} \mathrm{C}$, a precipitate formed which was filtered off. $\mathrm{Y}=84 \%$.

\section{Method II}

A solution of $0.388 \mathrm{~g}$ of embonic acid in $5 \mathrm{~cm}^{3}$ of $1 \mathrm{M} \mathrm{NaOH}$ was prepared at room temperature. In a beaker, $0.372 \mathrm{~g}$ of trazodone free base was dissolved in $5 \mathrm{~cm}^{3}$ of $1 \mathrm{M}$ $\mathrm{HCl}$. The embonic acid solution was added portionwise to the trazodone solution while stirring. The resulting mixture was adjusted to $\mathrm{pH}=7.0$. After cooling to $4{ }^{\circ} \mathrm{C}$, the resulting precipitate was filtered off. $\mathrm{Y}=63 \%$. 
T:EM. UPLC-MS $t_{\mathrm{M}} 3.87 \mathrm{~min}$. Elemental analysis, $\left.\% \mathrm{C}=61.28, \% \mathrm{H}=4.39, \% \mathrm{~N}=3.19\right) .{ }^{1} \mathrm{H}-$ NMR (300 MHz, DMSO) $\delta 8.39$ (s, 2H, ArH), 8.15 (d, J = 8.6 Hz, 2H, ArH), 7.84 (dd, J = 15.4, $7.5 \mathrm{~Hz}, 3 \mathrm{H}, \mathrm{ArH}), 7.34-7.12(\mathrm{~m}, 7 \mathrm{H}, \mathrm{ArH}), 7.03(\mathrm{~s}, 1 \mathrm{H}, \mathrm{ArH}), 6.95(\mathrm{~d}, J=8.3 \mathrm{~Hz}, 1 \mathrm{H}, \mathrm{ArH})$, $6.85(\mathrm{~d}, J=7.7 \mathrm{~Hz}, 1 \mathrm{H}, \mathrm{ArH}), 6.66-6.58(\mathrm{~m}, 1 \mathrm{H}, \mathrm{ArH}), 4.76\left(\mathrm{~s}, 4 \mathrm{H}, \mathrm{CH}_{\text {Alif-Pam }}\right), 4.02$ (dd, $J=12.2,6.4 \mathrm{~Hz}, 2 \mathrm{H}, \mathrm{CONCH}), 3.17\left(\mathrm{dd}, J=20.7,11.3 \mathrm{~Hz}, 8 \mathrm{H}, \mathrm{CH}_{\text {Pip }}\right), 2.18(\mathrm{~d}, J=6.5 \mathrm{~Hz}$, $\left.2 \mathrm{H}, \mathrm{NCH}_{\text {Alif }}\right), 1.30\left(\mathrm{dd}, J=14.6,7.4 \mathrm{~Hz}, 2 \mathrm{H}, \mathrm{CH}_{\text {Alif }}\right)$. FT-IR $\left(\mathrm{cm}^{-1}\right), 3280(\mathrm{O}-\mathrm{H}), 2970(\mathrm{C}-\mathrm{H}$ Ar), 2949; $2840(\mathrm{C}-\mathrm{H}), 1657(\mathrm{C}=\mathrm{O}), 1633(\mathrm{C}=\mathrm{N}), 1594 ; 1453(\mathrm{C}=\mathrm{C}), 1353 ; 1205(\mathrm{C}-\mathrm{O}), 1339$ $(\mathrm{C}-\mathrm{N}), 738(\mathrm{C}-\mathrm{Cl})$.

\subsection{Powder X-ray Diffraction (PXRD)}

Powder X-ray diffraction patterns for a bulk sample of T:OHN (after recrystallization) were recorded at room temperature on a Bruker Advance D8 diffractometer (Bruker, Billerica, MA, USA) equipped with a LYNXEYE position sensitive detector using $\mathrm{CuK} \alpha$ radiation $(\lambda=0.15406 \mathrm{~nm})$. The data were collected in the Bragg-Brentano $(\theta / \theta)$ horizontal geometry (flat reflection mode) between $4^{\circ}$ and $50^{\circ}(2 \theta)$ in a continuous scan using $0.03^{\circ}$ steps and $384 \mathrm{~s} / \mathrm{step}$. The diffractometer incident beam path was equipped with a $2.5^{\circ}$ Soller slit and a $1.14^{\circ}$ fixed divergence slit, while the diffracted beam path was equipped with a programmable anti-scatter slit (fixed at $2.20^{\circ}$ ), a $\mathrm{Ni} \beta$-filter, and a $2.5^{\circ}$ Soller slit. The diffraction pattern is presented in Figure S3 in the Supplementary Materials file and compared to the pattern simulated from single crystal final refinment data. These results confirm sample purity and homogeneity.

\subsection{Single Crystal X-ray Diffraction (SCXRD)}

X-ray reflections for T:OHN were measured at room temperature on a Rigaku Oxford Diffraction Gemini A Ultra diffractometer (Rigaku Corporation, Tokyo, Japan) using mirror monochromated $\mathrm{CuK} \alpha$ radiation $(\lambda=1.54184 \AA)$. Data collection, cell refinement, and data reduction were performed with CrysAlisPro software (CrysAlisPro 1.171.39.46, Rigaku OD, 2018). The empirical absorption corrections using spherical harmonics, implemented in the multiscan algorithm were performed. The structure was solved with the SHELXT [39] structure solution program using Intrinsic Phasing and refined with the SHELXL refinement package [40] using Least Squares minimization. implemented in the OLEX2 v.1.3 suite [41]. All non-hydrogen atoms were refined anisotropically. $\mathrm{H}$ atoms on $\mathrm{C}$ atoms were added to the structure model at geometrically idealized positions and refined as riding atoms, with $\mathrm{Uiso}(\mathrm{H})=1.2 \times \mathrm{Ueq}(\mathrm{CH})$ and $1.5 \mathrm{U} \times \mathrm{eq}\left(\mathrm{CH}_{3}\right)$. $\mathrm{H}$ atoms of hydroxy and amino groups were located from a Fourier map and refined with a fixed isotropic parameter of the parent atom equal to $1.2 \times \mathrm{Ueq}$ and $1.5 \mathrm{U} \times \mathrm{eq}$ for $\mathrm{NH}$ and $\mathrm{OH}$, respectively. Water molecule was refined as a rigid group (AFIX 6). Molecular diagrams were generated using ORTEP-3 for Windows [26] (Figure 3), Diamond [42] (Figure S4), and Mercury 2.0 [25]. (Figures S5 and S6) programs whereas geometrical parameters were calculated using OLEX2 [41] and Platon package [43,44]. Crystal Data for T:OHN: $\mathrm{C}_{30} \mathrm{H}_{32} \mathrm{ClN}_{5} \mathrm{O}_{5}:(M=578.05 \mathrm{~g} / \mathrm{mol})$ : monoclinic, space group $P 2_{1} / n$ (no. 14), $a=8.17642(17) \AA, b=36.3453(5) \AA, c=10.12988(19) \AA, \beta=109.651(2)^{\circ}, V=2835.01(10) \AA^{3}$, $\mathrm{Z}=4, \mathrm{~T}=298.15 \mathrm{~K}, \mu(\mathrm{Cu} \mathrm{K} \alpha)=1.600 \mathrm{~mm}^{-1}$, Dcalc $=1.354 \mathrm{~g} / \mathrm{cm}^{3}, 60220$ reflections measured $\left(9.586^{\circ} \leq 2 \Theta \leq 134.566^{\circ}\right), 5065$ unique $\left(R_{\text {int }}=0.0768, R_{\text {sigma }}=0.0254\right)$ which were used in all calculations. The final $R_{1}$ was $0.0438(\mathrm{I}>2 \sigma(\mathrm{I}))$ and $w R_{2}$ was 0.1163 (all data). CCDC deposition number: 2051183.

\subsection{Solid-State Nuclear Magnetic Resonance (SSNMR)}

The solid-state ${ }^{13} \mathrm{C}-\mathrm{NMR}$ spectra were obtained on a Bruker Avance $400 \mathrm{WB}$ (Bruker, Rheinstetten, Germany) utilizing a ${ }^{13} \mathrm{C}$ resonant frequency of $100.61 \mathrm{MHz}$ (magnetic field strength of $9.39 \mathrm{~T})$. Approximately $100 \mathrm{mg}$ of crystalline sample was packed into a zirconium rotor with a Kel-F cap. The cross-polarization, magic angle spinning (CP-MAS) pulse sequence was used for spectral acquisition. Each sample was spun at a frequency of $8 \mathrm{kHz}$, and the magic angle setting was calibrated by the $\mathrm{KBr}$ method. Each data set 
was subjected to an $8 \mathrm{~Hz}$ line broadening factor and subsequently, Fourier transformed and phase corrected to produce a frequency domain spectrum. The chemical shifts were referenced to TMS using adamantane as an external secondary standard. The optimized recycle delay for $\mathrm{T}: \mathrm{HCl}$ and $\mathrm{T}: \mathrm{OHN}$ was $170 \mathrm{~s}$ and $50 \mathrm{~s}$, respectively. The NMR spectra were processed with the ACD/SpecManager NMR program (version 10.0, Advanced Chemistry Development, Inc., Toronto, ON, Canada).

\subsection{GIPAW DFT Calculations}

The quantum-chemical calculations of geometry optimization and NMR shielding constants were carried out with the CASTEP $[28,29]$ program implemented in the Materials Studio 6.1 software (Accelrys Software Inc.: San Diego, CA, USA. 2013) using the planewave pseudopotential formalism and the Perdew-Burke-Ernzerhof (PBE) [45] exchangecorrelation functional, defined within the generalized gradient approximation (GGA) [46], the calculations were done with ultrasoft pseudopotentials calculated on the fly. The quality of calculations was set to fine as implemented in the CASTEP standards. CASTEP default values for the geometry convergence criteria were used. The kinetic energy cutoff for the plane waves was set to $550 \mathrm{eV}$. Brillouin zone integration was performed using a discrete $2 \times 2 \times 1$ for Monkhorst-Pack k-point sampling for a primitive cell. The computation of shielding tensors was performed using the Gauge Including Projector Augmented Wave Density Functional Theory (GIPAW) method of Pickard et al. In the calculations the experimental X-ray structures were used, but the positions of all atoms were optimized, while the cell parameters were fixed. To compare the theoretical and experimental data, the calculated chemical shielding constants $\left(\sigma_{\text {iso }}\right)$ were converted to chemical shifts $\left(\delta_{\text {iso }}\right)$, using the following equation: $\delta_{\text {iso }}=\left(\sigma_{\mathrm{Gly}}+\delta_{\mathrm{Gly}}\right)-\sigma_{\mathrm{iso}}$, where $\sigma_{\mathrm{Gly}}$ and $\delta_{\mathrm{Gly}}$ stand for the shielding constant and the experimental chemical shift, respectively, of the glycine carbonyl carbon atom (176.50 ppm).

\subsection{Preparation of Tablets}

Cylindrical tablets were prepared by direct compression of the appropriate trazodone compound with lactose monohydrate (lactose monohydrate; LA, p.a. grade). All tablets were prepared using a laboratory press fitted with a $14 \mathrm{~mm}$ flat-faced punch and die set, applying $5 \mathrm{t}$ force for $30 \mathrm{~s}$. Each tablet contained $150 \mathrm{mg}$ lactose monohydrate and an appropriate trazodone compound equivalent to $75 \mathrm{mg}$ of trazodone (the amount corresponding to market preparations, e.g., Trittico). The amount of the active substance in the tablet: $75 \mathrm{mg} \pm 5 \%$. As a reference tablets with $\mathrm{T}: \mathrm{HCl}+\mathrm{LA}$ were used.

\subsection{In Vitro Dissolution Profile Studies}

Dissolution experiments were carried out using Erweka DT-80 (Erweka GmbH., Heusenstam, Germany) equipment with controlled temperature (at $36 \pm 1^{\circ} \mathrm{C}$ ) for $4 \mathrm{~h}$. In this method, hydrochloric acid solution (concentration $0.01 \mathrm{M}$ ) was used as dissolution medium. The rate of stirring for the whole experiment time was $50 \pm 2 \mathrm{rpm}$. In all formulations, the amount of trazodone was $75 \mathrm{mg}$. Prepared tablets were placed in $900 \mathrm{~cm}^{3}$ of acceptor fluid. For $240 \mathrm{~min}$ at appropriate intervals, $5 \mathrm{~cm}^{3}$ of the sample were taken. Samples were taken after 1, 2, 5, 10, 15, 30, 45, 60, 90, 120, 150, 180, 210, and $240 \mathrm{~min}$. To maintain the constant volume of the dissolution medium after each sampling the fresh portion of the medium was added. All samples were filtered with cellulose syringe filters with a membrane diameter of $0.45 \mu \mathrm{m}$ Millipore filter and diluted.

Shimadzu UV-1800 UV-Vis spectrophotometer (Shimadzu Co., Kyoto, Japan) was used to analyze all samples. To minimize possible errors because of overlapping peaks, the maximum in trazodone UV-Vis spectrum at $311 \mathrm{~nm}$ was used to calculate drug concentrations without any interferences. The calibration curve used in these studies was presented in Figure 6. At $311 \mathrm{~nm}$ wavelength, a saturated solution of lactose monohydrate has only negligible absorbance $(\sim 0.001)$. To calculate the drug release from each of the 
formulations based on the separately constructed calibration curve $\left(R^{2}>0.994\right)$ the mean of 3 determinations was used (Figure 7).

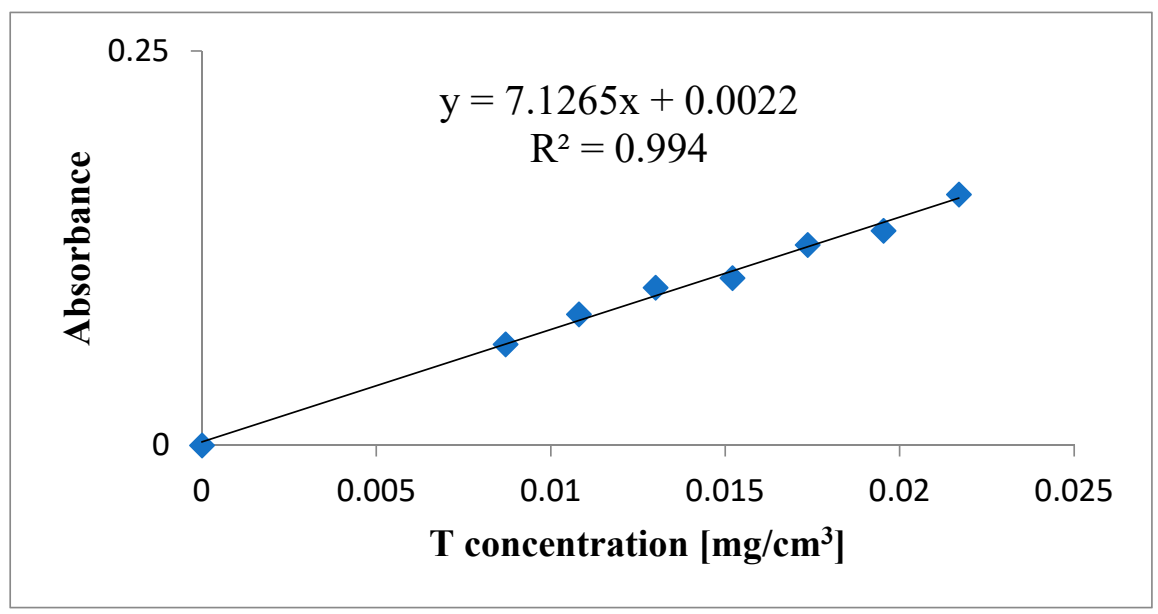

Figure 6. Calibration curve.

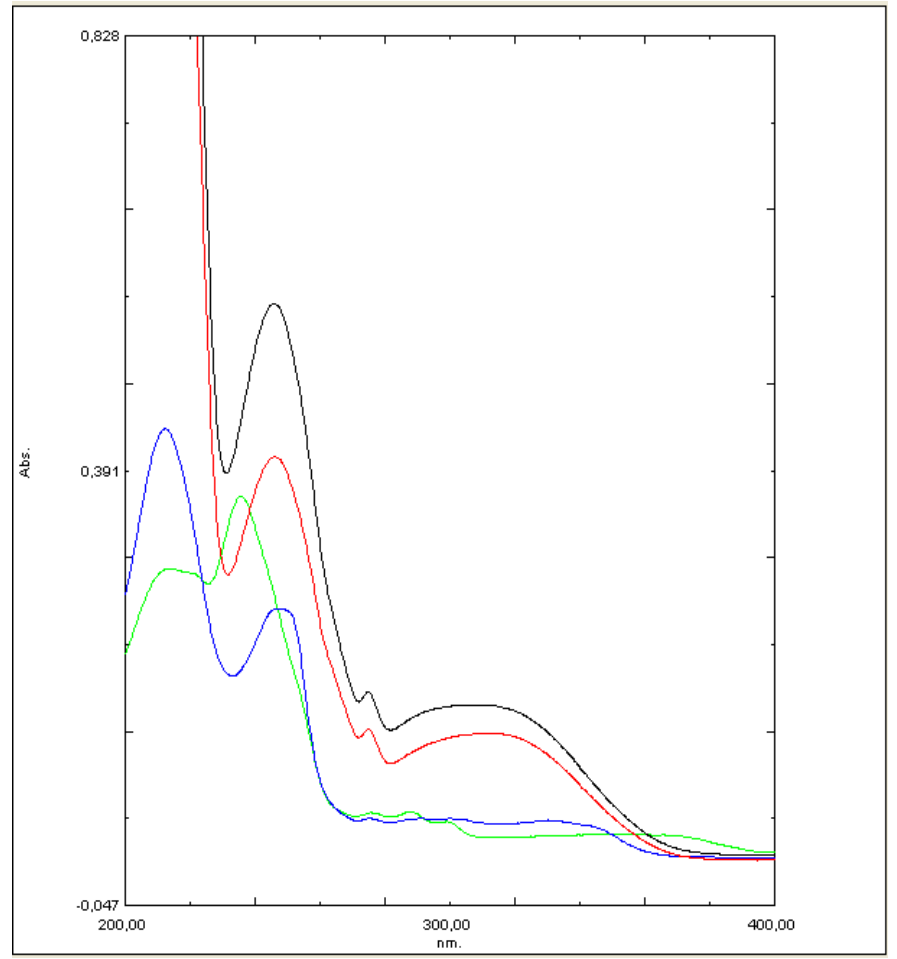

Figure 7. Absorbance curve for the tested compounds: (black T:HCl; red T:HBr; blue T:OHN; green T:EM).

UPLC-MS analysis conditions: Waters UPLC with PDA detector. Column: $1.7 \mu \mathrm{m}$ Aquity UPLC BEH C18 (Waters Corporation, Milford, MA, USA). Mobile phase: methanol: water + formic acid $(4: 6+0.1 \%, v / v)$. Ionization method: electrospray. Detector: quadrupole. Mass spectra were recorded with positive mode. ${ }^{1} \mathrm{H}-\mathrm{NMR}$ : Bruker $400 \mathrm{MHz}$ instrument (Bruker, Rheinstetten, Germany) with TMS (trimethylsilane) as the internal standard.

\section{Conclusions}

The search for simple and at the same time economically and ecologically beneficial methods of synthesis of complex chemical molecules is currently the main goal of modern organic synthesis. In this work, a new method of trazodone synthesis under microwave 
irradiation was used, and then two new trazodone salts, $\mathrm{T}: \mathrm{HBr}$ and $\mathrm{T}: \mathrm{OHN}$, were obtained in two (or three) different ways. To determine their therapeutic usefulness, we evaluated the dissolution profiles of trazodone from tablets containing tested salts with added lactose monohydrate. It turned out that the trazodone salt T:HBr showed a much faster release time of the active substance compared to the reference $\mathrm{T}: \mathrm{HCl}$ salt. On the other hand, T:OHN showed a slow-release profile of the active substance concerning the commercially available hydrochloric salt. Changing the dissolution profile of the drug (indicating slower release) may be useful when designing new formulations containing this drug. Based on these preliminary studies, it may be tempted to state that the salts of trazodone with small anions (T:HCl, T:HBr), due to only weak interactions occurring in the crystal lattice, are released from the tablet faster than salts containing much larger anions (T:OHN, T:EM). Spacious anions, especially those with aromatic substituents or H-bond active groups, create more significant interactions with the cation, making them more difficult to break, which could explain the retarded release time of the drug.

Supplementary Materials: The following are available online. Figure S1: Comparison of experimental and teoretical chemical shifts of carbon-13 of T:HCl, Figure S2. Comparison of experimental and teoretical chemical shifts of carbon-13 of T:OHN, Figure S3. Experimental powder X-ray diffraction pattern for bulk T:OHN sample (upper chart) and simulated from single crystal data (lower chart), Figure S4. Weak interactions motives found in T:OHN (a) and T:HCl (b) crystals, Figure S5. Packing diagram for T:OHN crystal. View along [101] direction, Figure S6. Packing diagram for T:HCl crystal. View along [010] direction Table S1: ${ }^{13} \mathrm{C} \mathrm{CP} / \mathrm{MAS}$ NMR chemical shifts (ppm) of T:HCl and T:OHN., Table S2. Geometry of main weak intermolecular interactions in T:OHN crystal, Table S3 Geometry of main weak intermolecular interactions in T:HCl crystal.

Author Contributions: Conceptualization, J.J. and E.P.; methodology, J.J., P.Z., A.D., Z.M. (synthesis), A.K. (in vitro dissolution profile studies), I.D.M. (SCXRD) and E.P. (SSNMR, GIPAW DFT calculations); investigation, J.J. and E.P.; writing-original draft preparation, J.J., I.D.M., P.Z., A.K. and E.P.; writing-review and editing, J.J., I.D.M., A.D. and E.P.; visualization, J.J., A.K., I.D.M. and E.P.; supervision, J.J. and E.P. All authors have read and agreed to the published version of the manuscript.

Funding: "Innovation Incubator 2.0" The program is financed by the non-competitive project "Support for the management of scientific research and commercialization of R\&D results in scientific units and enterprises" , implemented under the Smart Growth Operational Program 2014-2020 (Measure 4.4).

Conflicts of Interest: The authors declare no conflict of interest.

Sample Availability: Samples of compounds T:HBr and T:OHN are available from the authors.

\section{References}

1. Baiocchi, L.; Giannangeli, M. Synthesis of trazodone and its possible metabolites. Boll. Chim. Farm. 1974, 113, 152-164. [PubMed]

2. Szyndler, J.; Skórzewska, A.; Płaźnik, A. Leki blokujące receptory serotoninowe oraz hamujące wychwyt zwrotny serotoniny (SARI) w terapii zaburzeń psychicznych. Farmakoter. Psychol. Neurol. 2003, 3, 39-51.

3. Burke, M.J.; Preskorn, S.E.E. Short-term treatment of mood disorders with standard antidepressants. In Psychopharmacology: The Fourth Generation of Progress; Bloom, F.E., Kupfer, D.J., Eds.; Raven Press Ltd.: New York, NY, USA, 1995; pp. $1053-1065$.

4. Jarema, M.; Dudek, D.; Landowski, J.; Heitzman, J.; Rabe-Jabłońska, J.; Rybakowski, J. Trazodon-The antidepressant: Mechanism of action and its position in the treatment of depression. Psychiatr. Polska 2012, 45, 611-625.

5. Woron, J.; Adamczyk, A.; Malec-Milewska, M.; Jakowicka-Wordliczek, J. Stosowanie koanalgetyków u pacjentów z bólem neuropatycznym w przebiegu choroby nowotworowej. Palliat. Med. Pract. 2014, 8, 85-90.

6. Cusack, B.; Nelson, A.; Richelson, E. Binding of antidepressants to human brain receptors: Focus on newer generation compounds. Psychopharmacology 1994, 114, 559-565. [CrossRef]

7. Jaśkowska, J. Method for the Preparation of Trazodone. WO2018169420 A1, 20 September 2018.

8. Russell, T.L.; Berardi, R.R.; Barnett, J.L.; Dermentzoglou, L.C.; Jarvenpaa, K.M.; Schmaltz, S.P.; Dressman, J.B. Upper Gastrointestinal pH in Seventy-Nine Healthy, Elderly, North American Men and Women. Pharm. Res. 1993, 10, 187-196. [CrossRef]

9. Persson, E. Drug dissolution under physiologically relevant conditions in vitro and in vivo. Acta Univ. Ups. 2006, $39,65$.

10. Schiller, C.; Frohlich, C.-P.; Giessmann, T.; Siegmund, W.; Monnikes, H.; Hosten, N.; Weitschies, W. Intestinal fluid volumes and transit of dosage forms as assessed by magnetic resonance imaging. Aliment. Pharmacol. Ther. 2005, 22, 971-979. [CrossRef]

11. Haznar, D.; Garbacz, G. Wybrane aspekty technologii leków o modyfikowanym uwalnianiu. Farm. Pol. 2009, 65, 749-757. 
12. Sznitowska, M.; Żebrowska, W. Doustne postacie leku o modyfikowanym uwalnianiu. Cz. III-Dojelitowe postacie leku oraz tabletki o nietypowym profilu uwalniania lub konstrukcji. Ordynator Leków 2004, 4, 27-35.

13. Qiu, Y.; Zhang, G. Research and Development Aspects of Oral Controlled Release Dosage Forms. In Handbook of Pharmaceutical Controlled Release Technology; Marcel Dekker: New York, NY, USA, 2000; pp. 465-505.

14. Palazzo, G.; Silvestrini, B. Aziende Chimiche Riunite Angelini Francesco Acraf Spa, S-Triazole-[4,3-a]-pyridine Derivatives and Processes for their Preparation. GB 1117068, 12 June 1968.

15. Garrone, B.; Durando, L.; Calisti, F. Aziende Chimiche Riunite Angelini Francesco Acraf Spa, Brevet Spécial de Medicament. Nouveau Médicament à Action AntiDepressive. FR 8135, 10 August 1970.

16. Ware, E.C.; Lu, D.R. An Automated Approach to Salt Selection for New Unique Trazodone Salts. Pharm. Res. 2004, 21, 177-184. [CrossRef] [PubMed]

17. Palazzo, G.; Silvestrini, B. TRIAZOLE-4,3-al-PYRIDINES. U.S. Patent 3,381,009, 30 April 1968.

18. Plater, M.J.; Harrison, W.T. The complexation of 2,4-dinitrophenol with basic drugs: Acid + base = salt. J. Chem. Res. 2019, 43, 281-286. [CrossRef]

19. Babor, M.; Nievergelt, P.P.; Čejka, J.; Zvoníček, V.; Spingler, B. Microbatch under-oil salt screening of organic cations: Single-crystal growth of active pharmaceutical ingredients. IUCrJ 2019, 6, 145-151. [CrossRef] [PubMed]

20. Nievergelt, P.P.; Babor, M.; Čejka, J.; Spingler, B. A high throughput screening method for the nano-crystallization of salts of organic cations. Chem. Sci. 2018, 9, 3716-3722. [CrossRef]

21. Jaśkowska, J.; Zaręba, P.; Śliwa, P.; Pindelska, E.; Satala, G.; Majka, Z. Microwave-Assisted Synthesis of Trazodone and Its Derivatives as New 5-HT1A Ligands: Binding and Docking Studies. Molecules 2019, 24, 1609. [CrossRef] [PubMed]

22. Jaśkowska, J.; Zaręba, P.; Drabczyk, A. Nowe Sole Trazodonu, Sposoby Wytwarzania Nowych Soli Trazodonu i Zastosowanie Nowych Soli Trazodonu. P434293, 12 June 2020.

23. Groom, C.R.; Bruno, I.J.; Lightfoot, M.P.; Ward, S.C. The Cambridge Structural Database. Acta Crystallogr. 2016, 72, 171-179. [CrossRef]

24. Fillers, J.P.; Hawkinson, S.W. The structure of 2-\{3-[4-(m-chlorophenyl)-1-piperazinyl]propyl\}-s-triazolo[4,3-a]pyridin-3(2H)-one hydrochloride, trazodone hydrochloride. Acta Crystallogr. 1979, 35, 498-500. [CrossRef]

25. Macrae, C.F.; Bruno, I.J.; Chisholm, J.A.; Edgington, P.R.; McCabe, P.; Pidcock, E.; Rodriguez-Monge, L.; Taylor, R.J.; Van De Streek, J.; Wood, P.A. Mercury CSD 2.0-New features for the visualization and investigation of crystal structures. J. Appl. Crystallogr. 2008, 41, 466-470. [CrossRef]

26. Farrugia, L.J. WinGXsuite for small-molecule single-crystal crystallography. J. Appl. Crystallogr. 1999, 32, 837-838. [CrossRef]

27. Pickard, C.J.; Mauri, F. All-electron magnetic response with pseudopotentials: NMR chemical shifts. Phys. Rev. B 2001, 63, 245101. [CrossRef]

28. Yates, J.R.; Pickard, C.J.; Mauri, F. Calculation of NMR chemical shifts for extended systems using ultrasoft pseudopotentials. Phys. Rev. B 2007, 76, 024401. [CrossRef]

29. Blöchl, P.E. Projector augmented-wave method. Phys. Rev. B 1994, 50, 17953-17979. [CrossRef] [PubMed]

30. Segall, M.; Lindan, P.J.D.; Probert, M.J.; Pickard, C.J.; Hasnip, P.J.; Clark, S.J.; Payne, M.C. First-principles simulation: Ideas, illustrations and the CASTEP code. J. Phys. Condens. Matter 2002, 14, 2717-2744. [CrossRef]

31. Pindelska, E.; Madura, I.D.; Szeleszczuk, Ł.; Żeszko, A.; Jaśkowska, J.; Marek, P.H.; Kolodziejski, W. Alkyl Spacer Length and Protonation Induced Changes in Crystalline Psychoactive Arylpiperazine Derivatives: Single-Crystal X-ray, Solid-State NMR, and Computational Studies. Cryst. Growth Des. 2016, 16, 6371-6380. [CrossRef]

32. Chierotti, M.R.; Gobetto, R. Solid-state NMR studies of weak interactions in supramolecular systems. Chem. Commun. 2008, 1621-1634. [CrossRef]

33. Gobetto, R.; Nervi, C.; Chierotti, M.R.; Braga, D.; Maini, L.; Grepioni, F.; Harris, R.K.; Hodgkinson, P. Hydrogen Bonding and Dynamic Behaviour in Crystals and Polymorphs of Dicarboxylic-Diamine Adducts: A Comparison between NMR Parameters and X-ray Diffraction Studies. Chem. A Eur. J. 2005, 11, 7461-7471. [CrossRef]

34. Etter, M.C.; Macdonald, J.C.; Bernstein, J. Graph-set analysis of hydrogen-bond patterns in organic crystals. Acta Crystallogr. 1990, 46, 256-262. [CrossRef]

35. Subperiodic Groups. International Tables for Crystallography Volume E, 1st ed.; Kopský, V., Litvin, D.B., Eds.; International Union of Crystallography Online Edition, Kluwer Academic Publishers: Dordrecht, The Netherlands, 2006. [CrossRef]

36. Spackman, M.A.; Jayatilaka, D. Hirshfeld surface analysis. CrystEngComm 2009, 11, 19-32. [CrossRef]

37. McKinnon, J.J.; Jayatilaka, D.; Spackman, M.A. Towards quantitative analysis of intermolecular interactions with Hirshfeld surfaces. Chem. Commun. 2007, 3814-3816. [CrossRef]

38. Gilli, G.; Gilli, P. The Nature of the Hydrogen Bond: Outline of a Comprehensive Hydrogen Bond Theory. In International Union of Crystallography Monographs on Crystallography; Oxford University Press: Oxford, UK, 2009; Volume 23, p. 336. [CrossRef]

39. Sheldrick, G.M. SHELXT-Integrated space-group and crystal-structure determination. Acta Cryst. 2015, 71, 3-8. [CrossRef]

40. Sheldrick, G.M. Crystal structure refinement with SHELXL. Acta Cryst. 2015, 71, 3-8. [CrossRef]

41. Dolomanov, O.V.; Bourhis, L.J.; Gildea, R.J.; Howard, J.A.K.; Puschmann, H. OLEX2: A complete structure solution, refinement and analysis program. J. Appl. Crystallogr. 2009, 42, 339-341. [CrossRef]

42. Brandenburg, K. DIAMOND: Visual Crystal Structure Information System, Version 2.1d; Crystal Impact GbR: Bonn, Germany, 2004.

43. Spek, A.L. PLATON: A Multipurpose Crystallographic Tool; Utrecht University: Utrecht, The Netherlands, 1980-2020. 
44. Spek, A.L. Single-crystal structure validation with the program PLATON. J. Appl. Crystallogr. 2003, 36, 7-13. [CrossRef]

45. Perdew, J.P.; Burke, K.; Ernzerhof, M. Generalized Gradient Approximation Made Simple. Phys. Rev. Lett. 1996, $77,3865$. [CrossRef] [PubMed]

46. Perdew, J.P.; Zunger, A. Self-interaction correction to density-functional approximations for many-electron systems. Phys. Rev. B 1981, 23, 5048-5079. [CrossRef] 